\title{
Effect of Safety Culture, Safety Leadership, and Safety Climate on Employee Commitments and Employee Performance PT Pelindo III (Persero) East Java Province
}

\author{
Benny Agus Setiono, ${ }^{1, *}$ | Ida Ayu Brahmasari ${ }^{1}$ | Siti Mujanah ${ }^{1}$ \\ ${ }^{1}$ Faculty of Economics, Universitas 17 Agustus 1945 Surabaya, Indonesia
}

\begin{abstract}
This study aims to analyze the effects of safety culture, safety leadership and the safety climate on organizational commitment and employee performance. Using the survey method, responses from 218 respondents were collected to understand the complete picture of a port service industry in Indonesia. Data were analyzed with Structural Equation Model (SEM) and it reveals that each safety culture variable, safety climate safety leadership, and employee commitment has a positive and significant impact on employee performance. Organizational commitment variables may enhance the effects of safety culture, safety leadership and a safety climate on employee performance.
\end{abstract}

Keywords: safety culture, safety leadership, safety climate, employee commitment, employee performance

\section{Introduction}

Organizations require human resources as managers of the system to achieve its objectives so that the system must run in the management must pay attention to some important aspects related to safety work Employees. One of these important aspects can be spelled out through the implementation of a safety management system. Occupational-related phenomena in developing countries like Indonesia are still very high. According to data from the International Labor Organization (ILO), in Indonesia on average per year, there are 99,000 cases of work accidents. Of the total number, about 70 percent of fatal deaths and disabilities for life. Data from BPJS Employment by the end of 2015 shows that there have been work accidents of 105,182 cases with 2,375 deaths, or not less than six workers died every day due to accidents. The figure is quite high compared to European countries that only two people die per day due to work accidents.

Cooper (2000) suggests that individual commitment is a dimension of safety culture and affects safety performance, while Cheyne et al. (1998), Mohamed (2002), suggest that individual commitment is one of the major factors of safety culture. Smith and Wadsworth (2009) research state that a safety culture is consistently and independently linked to employee commitment and safety performance. Flin et al. (1996), safety leadership is associated with shaping employee commitment and safety performance. Research from Xuesheng (2012), suggests that safety leadership, the safety climate, positively affects employees' commitments. Paivinen (2017), efficient safety leadership along with safety culture and a safe climate affect employee safety and performance outcomes. Safety leadership is recognized as one of the key factors affecting performance.

Research conducted Kamal et al. (2014), the results explain, that safety leadership has a significant effect on employee performance. Occupational safety culture has no effect on employee performance.

\footnotetext{
${ }^{1}$ Corresponding author. Email: bennyagussetiono@yahoo.co.id
} 
Work safety climate affects employee performance. Safety Culture is an interrelation of three elements, namely organization, workers, and employment. This suggests that a safety culture should be implemented by all available resources, at all levels and not just for Cooper (2001). Further Safety Culture is measured using Management Commitments, Regulations, and Procedures, Communication, Employee Engagement, Competence, Work Environment (Cooper, 2001). Safety leadership is a leadership role as a key to success in building a strong safety culture in high-risk industries. Furthermore, Safety Leadership is measured using Leaders as Role Models, Learner Leaders, General Safety Requirements International Atomic Energy Agency, IAEA GS-R3.

Safety Climate is the fulfillment and participation of individuals on safeguard activities in the workplace (Griffin and Neal, 2000). Furthermore, the safety climate is measured using Management Value, Safety Communication, Safety Practices, Safety Equipment. Employee Commitment is a psychological construct that is characteristic of organizational member relationships with their organizations and has implications for individual decisions to continue membership in organizing (Meyer and Allen, 2009). Furthermore, employee commitment is measured by using: Affective commitment, Continuance commitment, Normative commitment. Mangkunegara (2006) argued that employee performance is the result of work in quality and quantity achieved by an employee in performing their duties in accordance with the responsibilities given to him. Furthermore, employee performance is measured by using quantity, quality, reliability, and attendance.

\section{Method}

We choose survey method by using questionnaire with 5-points Likert scale. The questionnaire is distributed to 300 employees of PT Pelindo III (Persero). One month after the questionnaire collected, we receive responses from 218 respondents. From the questionnaire, we could understand the complete picture of a port service industry in Indonesia. Variables we collect are related to safety culture, safety leadership, safety climate, employee commitment, and employee performance. Data we obtained from the survey were analyzed with Structural Equation Model (SEM) using AMOS Software. The result of this study will be described in the next section.

\section{Result}

The result of the goodness-of-fit analysis shows that all suitability of model gives index according to the recommended (fit).

Table 1. Goodness of fit Value

\begin{tabular}{llrc}
\hline Criteria & Results & Cut-Off & Description \\
\hline Cmin/df & 1.905 & $<3.00$ & Fit \\
RMSEA & 0.058 & $\leq 0.08$ & Fit \\
GFI & 0.944 & $\geq 0.90$ & Fit \\
AGFI & 0.925 & $\geq 0.90$ & Fit \\
TLI & 0.961 & $\geq 0.95$ & Fit \\
CFI & 0.994 & $\geq 0.95$ & Fit \\
RMR & 0.018 & $\leq 0.05$ & Fit \\
NFI & 0.983 & $>0.90$ & Fit \\
\hline
\end{tabular}

Based on SEM analysis result which can be seen in table 2 it is known that Safety culture has an effect on employee commitment of PT Pelindo III East Java. The loading value shows the number of 0.519 and the critical ratio value of 4.284 is greater than the value of $Z$ of 1.96 and has the value Probability or standard error below 0.00 , this means that the hypothesis indicating that the Safety Culture significantly affect employee commitment, So Hypothesis 1 is accepted, meaning that if the safety culture is upgraded it will bring more committed employees to the company. 
Table 2. Results of Examining Hyphotesized for Structural Equation Model

\begin{tabular}{|c|c|c|c|c|c|c|c|}
\hline Hip & Effect & & & Coefficient & C.R. & Prob. & Description \\
\hline $\mathrm{H}_{1}$ & Safety culture & $\rightarrow$ & $\begin{array}{l}\text { Employee } \\
\text { commitment }\end{array}$ & 0.519 & 4.284 & 0.000 & Significant \\
\hline $\mathrm{H}_{2}$ & Safety culture & $\rightarrow$ & $\begin{array}{l}\text { Employee } \\
\text { performance }\end{array}$ & 0.859 & 7.088 & 0.000 & Significant \\
\hline $\mathrm{H}_{3}$ & $\begin{array}{l}\text { Safety } \\
\text { leadership }\end{array}$ & $\rightarrow$ & $\begin{array}{l}\text { Employee } \\
\text { commitment }\end{array}$ & 0.511 & 4.280 & 0.000 & Significant \\
\hline $\mathrm{H}_{4}$ & $\begin{array}{l}\text { Safety } \\
\text { leadership }\end{array}$ & $\rightarrow$ & $\begin{array}{l}\text { Employee } \\
\text { performance }\end{array}$ & 0.405 & 6.457 & 0.000 & Significant \\
\hline $\mathrm{H}_{5}$ & Safety climate & $\rightarrow$ & $\begin{array}{l}\text { Employee } \\
\text { commitment }\end{array}$ & 0.701 & 7.878 & 0.000 & Significant \\
\hline $\mathrm{H}_{6}$ & Safety climate & $\rightarrow$ & $\begin{array}{l}\text { Employee } \\
\text { performance }\end{array}$ & 0.630 & 3.939 & 0.043 & Significant \\
\hline $\mathrm{H}_{7}$ & $\begin{array}{l}\text { Employee } \\
\text { commiment }\end{array}$ & $\rightarrow$ & $\begin{array}{l}\text { Employee } \\
\text { performance }\end{array}$ & 0.523 & 4.406 & 0.000 & Significant \\
\hline
\end{tabular}

PT Pelindo III of East Java Province now has a strong safety culture characterized by the core values of the organization held and agreed and run by its members. The more members of the organization receive the core values of the safety culture, the greater their commitment to the values of the safety culture. Safety culture has a positive and significant impact on employee performance in PT Pelindo III. This is indicated by the value of loading with the number of 0.859 and the critical ratio value of 7.088 this shows a larger number of $Z$-score 1.96, and the probability number of significance shows the number 0.000 or below 0.05 so Hypothesis 2 accepted, meaning that If safety culture is improved then employee performance will increase.

With a strong safety culture condition PT. Pelindo III of East Java Province will be able to direct employees to behave and act, because organizations that have strong culture have values and codes of conduct for their employees, so that employee performance can be increased in accordance with the mission and goals set by the organization. Safety leadership has a positive and significant impact on employee commitment in PT Pelindo III. This is indicated by the value of loading with the number of 0.511 and the critical ratio value of 4.280 this shows a larger number of Z-score 1.96, and the number of probability significance shows the number 0.000 or below 0.05 so Hypothesis 3 accepted, meaning that If safety leadership is improved then employee commitment will increase.

Safety leadership has a positive and significant impact on Employee Performance in PT Pelindo III. This is indicated by the loading value with the number of 0405 means that each safety leadership is improved then the performance will increase by 0.405 , the critical ratio value of 6.457 indicates that the value of Critical Value is greater than the value of Z-score of 1.96 , and the probability significance indicates This 0.000 number means to show a number below 0.05 so Hypothesis 4 is accepted, it means that if the leadership of safety is increased then employee performance will increase.

The result of hypothesis testing above shows that the safety leadership applied in PT Pelindo III East Java Province can improve safety in a sustainable manner. Safety leadership is characterized as a knowledge-sharing leader, implementing knowledge transfer and sharing of safety knowledge to subordinates so as to affect employee performance. The safety climate has a positive and significant impact on employee commitment. This is indicated by the value of loading with the number of 0.701 means that if Climate safety is increased, it will increase the employee commitment of 0.701 , the critical ratio value of 7,878 indicates that the value of Critical Value greater than the value of Z-score of 1.96, and the probability significance Shows this 0.000 number indicates a number below 0.05 so Hypothesis 5 is accepted, meaning that if the safety climate is upgraded, then the employee's commitment will increase. 
The results showed that the safety climate can increase employee commitment, namely the safety climate associated with how the attitude of the management of PT. Pelindo III of East Java Province on safety and perception that safety is important, employees' perceptions of safety issues are communicated, management's readiness provides safety equipment and responds quickly to hazards arising, employee perceptions of aspects of safety training and adequacy and availability Safety equipment will increase the Affective commitment or commitment that refers to the emotional relationship of members to the organization, Continuance commitment, which is a commitment that refers to the desire of employees to remain in the organization and Normative commitment, which is a commitment that refers to the feelings of employees in which they are required to remain in the organization because of pressure from others.

Safety climate has a positive and significant impact on employee performance at PT. Pelindo III East Java Province. This is indicated by the value of loading with the number of 0.630 means that if the Climate K3 increased, it will improve employee performance of 0.630 , the critical ratio of 3.939 indicates that the value of Critical Value greater than the value of Z-score of 1.96, and the number of probability significance Shows the number 0.043 this means showing the numbers below 0.05 so Hypothesis 6 accepted, meaning that if the safety climate is increased, then the employee performance will rise.

Employee commitment has a positive and significant impact on employee performance at PT. Pelindo III East Java Province. This is indicated by the value of loading with the number of 0.523 means that if the Commitment of employees increases it will have an impact on employee performance improvement of 0.523 , the critical ratio value of 4.406 indicates that the value of Critical Value greater than the value of Z-score of 1.96, Probability significance indicates this 0.000 figure means. Shows a number below 0.05 so Hypothesis 7 is accepted, meaning that if the employee commitment is increased, then the employee performance will increase.

\section{Discussions and Conclusion}

The application of safety culture is an interrelation of the three elements, namely the organization, the workers, and the work in the implementation of work carried out by all available resources, at all levels reflected in several indicators such as management commitments, rules and procedures, communications, employee involvement, and the existing work environment within the company. This safety culture is important to develop because it can affect the commitment of employees who are individual behavior to continue their membership in the organization, whether affective commitment, i.e. the emotional relationship of members to the organization, ongoing commitment or the desire of employees to remain in the organization and normative commitment, Where they are required to remain in the organization due to pressure from others.

From the results of the above analysis shows how important it is to apply safety culture strongly in the company, especially to employees who have a rather high level of work risk hence safety culture is very important because with the application of high safety culture will have an impact on employee performance. This is probably due to safety which in the employee will feel safe and remain vigilant in carrying out the work considering the safety is important for individuals and organizations.

Leadership in occupational safety is the key to success in building a strong safety culture in highrisk industries. In this study safety leadership is measured by the following indicators (General Safety Requirements International Atomic Energy Agency), GS-R3 IAEA Leaders as Role Models, Leaders of learners, Leaders who share knowledge. PT Pelindo III is a company that runs the core business as a port service provider, has a key role to guarantee the continuity and smoothness of sea transportation. With the availability of adequate marine transportation infrastructure, PT. Pelindo III East Java Province is able to mobilize and stimulate the economic activities of the state and society. PT. Pelindo III of East Java Province is responsible for Shipping Safety, Port Operation, Water Transportation and Maritime Environment, so that in conducting its operational activities have a high enough risk for its employees so that a leadership-oriented and committed model of safety is needed which in turn will be able to provide a sense of Safe on his subordinates.

The results above show that the safety climate can improve employee performance, namely employee perceptions related to how the attitude of the management of PT. Pelindo III of East Java Province on safety and perception that safety is important, employees' perceptions of safety issues are communicated, management's readiness provides safety equipment and responds quickly to hazards 
arising, employee perceptions of aspects of safety training and adequacy and availability Safety equipment.

The results of this study indicate that employee commitment is very important in improving employee performance, this is because employees always support the goals of the organization and are willing to help to achieve these goals. Employee commitment to the organization can be demonstrated by the length of employees joining the organization and the tendency of employees to remain in the organization. Employee commitment is also formed because they do not want to disappoint colleagues or leaders. The impact if every individual in the organization has a high commitment to do the best for their respective jobs, will certainly affect the performance or survival of an organization.

\section{References}

Cheyne, A., Cox, S., Oliver, A. and Tomas, J.. (1998), "Modeling Safety Climate in The Prediction of Levels of Safety Activity", Work \& Stress, Vol. Vol. 12.

Cooper, D. (2001), Improving Safety Culture: A Practical Guide, Applied Behavior Sciences, Hill.

Cooper, M. (200o), "In mine safety, a meek watchdog", The New York Times, available at: http://www.nytimes.com.

Flin, R., Mearns, K., Gordon, R. and Fleming, M. (1996), "Risk perception by offshore workers on UK oil and gas", Safety Science, Vol. Vol. 22 No. No. 1-3, pp. 131-145.

Griffin, M.A. and Neal, A. (200o), "Perceptions of safety at work: A framework for linking safety climate to safety performance, knowledge and motivation", Journal of Occupational Health Psychology, Vol. 5, pp. 347-358.

Kamal, D., Heriansyah, H., and Masruroh. (2014), "Analysis of The Effect of Leadership on Safety Culture and Safety Climate and Its Impact on Safety Behavior of Pt. Sutra Mandiri”, Journal of Economics and Business, available at: http://library.binus.ac.id/.

Mangkunegara, A. (2006), Manajemen Sumber Daya Manusia Perusahaan, Remaja Rosdakarya, Bandung.

Meyer, J.P. and Allen, N.J. (2009), Commitment in the Workplace: Theory, Research and Application., Sage, Thousand Oaks, CA.

Mohamed, S. (2002), "Safety Climate in Construction Site Environment", Journal of Construction Engineering and Management, p. pp.375-384.

Paivinen, M. (2017), "Safety and Performance Excellence: How to Strategically Improve Safety Performance".

Smith, A.P. and Wadsworth, E.J.K. (2009), "Safety culture, advice and performance", Policy and Practice in Health and Safety.

Xuesheng, D. (2012), "Research on the Relationship Between Safety Leadership and Safety Climate in Coalmines", Journal Procedia Engineering, Vol. Vol 45. 